\title{
EFEKTIVITAS SEDIAAN SALEP EKSTRAK HERBA PEGAGAN (Centella asiatica (L) Urb) UNTUK PENYEMBUHAN LUKA PADA MENCIT JANTAN (Mus musculus albinus)
}

\author{
Moerfiah, Muztabadihardja, Santi Puspita Dewi \\ Program Studi Farmasi FMIPA-UNPAK Bogor \\ Email:moerfi_ah@yahoo.com
}

\begin{abstract}
ABSTRAK
Formula salep herba ekstrak pegagan (Centella asiatica (L) Urb) dalam penelitian ini dibuat dari 5 gram ekstrak pegagan sebagai zat aktif yang dicampur dengan berbagai basis, yaitu basis berminyak,emulsi dan larut air. Mencit jantan (20 ekor) yang sudah dilukai dengan scalpel steril sepanjang $1,5 \mathrm{~cm}$ dibagi menjadi 5 kelompok masing-masing 4 ekor dan mendapat perlakuan salep ekstrak pegagan sebagai berikut : Kelompok I diolesi dengan formula basis minyak, kelompok II formula basis emulsi, kelompok III formula basis larut air, kelompok IV ekstrak murni serta kelompok V diolesi betadin® sebagai kontrol positif. Bahan uji diberikan dua kali sehari selama 21 hari dan diamati pada hari ke-1, 3, 7, 14, 21. Hasil yang diperoleh, menunjukkan bahwa pada hari ke 14, bila dibandingkan dengan kontrol positif, maka kelompok I dan IV lebih efektif menyembuhkan luka dibandingkan kelompok II dan III. Pada hari ke 21 semua kelompok efektif menyembukan luka sama seperti kontrol positif.
\end{abstract}

Kata kunci: Pegagan, Salep, Kulit

\section{EFFECTIVENESS OF GOTU KOLA (Centella asiatica (L) Urb) HERBS EXTRACT OINTMENT FOR WOUND HEALING IN MALE MICE (Mus musculus Albinus)}

\begin{abstract}
Ointment formula of gotu kola extract (Centella asiatica $(\mathrm{L})$ Urb) in this study was made of 5 grams of Centella asiatica extract as an active substance that is mixed with a variety of bases, namely oily, emulsion and water-soluble bases. Male mice (20 animals) were already wounded with a sterile scalpel length of $1.5 \mathrm{~cm}$ were divided into five groups each of 4 mice and gotu kola extract ointment treated as follows: Group I smeared with oily base formula, the group II emulsion base formula, Group III water-soluble base formula, pure extract of Group IV and Group V smeared betadin ${ }^{\circledR}$ as a positive control. The test material was given twice daily for 21 days and observed on days $1,3,7,14,21$. The results obtained showed that at day 14, compared with the positive control, the group I and IV are more effective cure injuries than the group II and III. On day 21 all dose heal wounds effectively the same as a positive control.
\end{abstract}

Key words: Gotu kola (Centella asiatica (L) Urb), ointment, skin

\section{PENDAHULUAN}

Salah satu dari 10 jenis tanaman terlaris di dunia yang mempunyai potensi untuk dikembangkan sebagai tanaman obat adalah pegagan (Centella asiatica $(\mathrm{L})$ Urb) yang dapat digunakan sebagai obat luka (Endah dkk, 2003).

Luka adalah keadaan dimana kontinuitas jaringan rusak, yang disebabkan oleh pengaruh kimiawi, listrik atau radiasi (Direen, 1981). Untuk mencegah terjadinya 
infeksi bakteri diperlukan suatu antibakteri. . Tumbuhan pegagan khusus mengandung asiatikosida, berfungsi untuk memproduksi kolagen juga dapat mempercepat proses penyembuhan luka pada bagian permukaan kulit manusia. Proses ini terjadi karena aktivitas epidermis lapisan sel malpigi pada kulit tadi meningkat dan secara topikal dapat menyembuhkan. Selain itu dapat juga meningkatkan serta menguatkan jaringan kulit yang baru terbentuk, sehingga tidak mudah lagi rusak. Asiatikosida juga mempunyai daya antibakteri terhadap Staphylococcus aureus dan Escherichia colli. Adanya asiatikosida, riboflavin dan niasin membuat pegagan berfungsi sebagai anti inflamasi (Saktono, 2002).

Salep merupakan salah satu bentuk sediaan semi padat yang banyak digunakan dalam pengobatan kulit. Sebelum memberikan efek, zat aktif sediaan salep harus dapat dilepaskan dari basisnya, baru diabsorpsi melalui kulit. Hal ini dipengaruhi oleh beberapa faktor, baik faktor fisiologis maupun kimia fisika. Faktor kimia fisika tersebut meliputi koefisien difusi, konsentrasi dan kelarutan obat dalam basis. Sedangkan faktor fisiologi meliputi keadaan kulit, luas daerah permukaan dan banyaknya pemakaian (Anief, 2003).

Hingga saat ini belum ada penelitian untuk menguji khasiat ekstrak pegagan sebagai antiluka dalam bentuk formulasi salep. Bahan pembantu dalam formulasi yang baik seharusnya bersifat inert dan tidak mengurangi khasiat bahan aktif. Pemilihan basis yang baik harus melalui pertimbangan pertimbangan lebih dulu dengan melihat sifat dan masing- masing basis salep (Block, 1990 ; Ansel, 1989). Karena pada umumnya sifat polaritas senyawa bahan alam sukar diketahui dengan pasti maka perlu di teliti lebih lanjut pengaruh basis salep terhadap khasiat ekstrak pegagan.

\section{METODE PENELITIAN Bahan}

Bahan yang digunakan adalah herba Pegagan (Centella asiatica (L).Urban) dari seluruh bagian tanaman koleksi BALITTRO
(Balai Tanaman Obat dan Rempah). Mencit serta pellet, betadin ${ }^{\circledR}$ dan air suling. Bahan untuk pembuatan salep ekstrak pegagan seperti, cera alba, vaselin putih, setil alkohol, propilen glikol, natrium lauril sulfat, air suling, PEG 4000, stearil alkohol, gliserin.

\section{Alat}

Alat-alat penelitian yang digunakan antara lain: Alat-alat gelas, neraca analitik, rotavapor, termometer, mortir, cawan penguap, kertas perkamen, penangas air, pot plastik, bejana, pisau, batang pengaduk, corong, sudip dan scalpel.

\section{Cara Kerja}

\section{Pembuatan Ekstrak Herba Pegagan}

Ekstrak herba pegagan dibuat dengan cara maserasi, yaitu $250 \mathrm{~g}$ serbuk herba pegagan dengan $1.875 \mathrm{ml}$ etanol $70 \%$, ditutup dan dibiarkan selama 5 hari dan terlindung dari cahaya, sambil berulangulang diaduk. Setelah 5 hari sari diserkai, ampas diperas. Ampas ditambah etanol 70\% secukupnya diaduk dan diserkai, sehingga diperoleh seluruh sari sebanyak $2500 \mathrm{ml}$. Bejana ditutup, dibiarkan ditempat sejuk, terlindung dari cahaya, selama 2 hari. Kemudian endapan dipisahkan. Kemudian dilakukan penguapan pada suhu $50^{\circ} \mathrm{C}$ dengan rotavapor sehingga sebagian besar alkohol menguap hingga diperoleh ekstrak kental.

\section{Pembuatan Sediaan Salep}

Sediaan salep dibuat sesuai dengan formula masing-masing tipe basis.

Tabel 1. Formula Sedian Salep Basis Berminyak

\begin{tabular}{cc}
\hline Bahan & Jumlah (g) \\
\hline R/Cera alba & 4.75 \\
Vaselin putih & 90.07 \\
Butilhidroksianisol & 0.01 \\
(BHA) & \\
Metil paraben & 0.15 \\
Propil paraben & 0.02 \\
Ekstrak kental & 5 \\
\hline
\end{tabular}

Sumber : (Rosanti 2003).
a. Cara pembuatan Sedian Salep Basis Berminyak: 
Cera alba dilelehkan diatas penangas air, vaselin putih ditambahkan, diaduk sampai homogen dan dingin. BHA yang telah dilarutkan dengan etanol dimasukkan kedalam basis salep digerus homogen. Metil paraben dan propil paraben yang telah dilarutkan dengan etanol dicampurkan dengan ekstrak. Ekstrak kental pegagan dicampurkan ke dalam basis sedikit demi sedikit sambil diaduk sampai homogen. Salep dikemas dalam wadah.

\section{b.Cara pembuatan Sedian Salep Basis Emulsi:}

Setil alkohol, cera alba, propilen glikol dilelehkan diatas penangas air pada suhu $65^{\circ} \mathrm{C}$ (fase I). Natrium lauril sulfat dilarutkan dalam air suling, dipanaskan diatas penangas air pada suhu $65^{\circ} \mathrm{C}$ (Fase II). Fase I dan fase II dicampurkan perlahan-lahan sambil diaduk di atas penangas air selama 10 menit. Campuran dituang dalam mortir sambil diaduk hingga dingin. BHA yang telah dilarutkan dengan etanol dimasukkan kedalam basis salep digerus homogen. Metil paraben dan propil paraben yang telah dilarutkan dengan etanol dicampurkan dengan ekstrak. Ekstrak kental pegagan dicampurkan ke dalam basis sedikit demi sedikit sambil diaduk sampai homogen. Salep dikemas dalam wadah.

Tabel 2. Formula Sedian Salep Basis Emulsi

\begin{tabular}{lc}
\hline \multicolumn{1}{c}{ Bahan } & Jumlah $(\mathbf{g})$ \\
\hline R/Cera alba & 0.95 \\
Setil alkohol & 14.22 \\
Propilen glikol & 9.48 \\
Na lauril sulfat & 1.90 \\
Air suling & 68.27 \\
Vaselin putih & 90.07 \\
Butilhidroksianisol & 0.01 \\
(BHA) & \\
Metil paraben & 0.15 \\
Propil paraben & 0.02 \\
Ekstrak kental & 5 \\
\hline Sumber : Rosanti, &
\end{tabular}

Sumber : Rosanti, 2003

\section{c.Cara pembuatan Sedian Salep Basis Larut Air}

Stearil alkohol, PEG 4000 dan gliserin dipanaskan diatas penangas air pada suhu $75^{\circ} \mathrm{C}$ (fase I). Natrium lauril sulfat dilarutkan dalam air suling dan dipanaskan diatas penangas air pada suhu $75^{\circ} \mathrm{C}$ (fase II). Fase I ditambahkan sedikit demi sedikit dalam mortir yang berisi fase II sambil diaduk hingga dingin. BHA yang telah dilarutkan dengan etanol dimasukkan ke dalam basis salep digerus homogen. Metil paraben dan propil paraben yang telah dilarutkan dengan etanol dicampurkan dengan ekstrak. Ekstrak kental pegagan dicam-purkan ke dalam basis sedikit demi sedikit sambil diaduk sampai homogen. Salep dikemas dalam wadah

Tabel 3. Formula Sedian Salep Basis Larut Air

\begin{tabular}{lc}
\hline \multicolumn{1}{c}{ Bahan } & Jumlah $(\mathbf{g})$ \\
\hline R/Na lauril sulfat & 0.95 \\
Na lauril sulfat & 1.90 \\
PEG 4000 & 18.97 \\
Stearil alcohol & 32.24 \\
Air suling & 14.22 \\
Gliserin & 28.44 \\
Butilhidroksianisol & 0.01 \\
Metil paraben & 0.15 \\
Propil paraben & 0.02 \\
Ekstrak kental & 5 \\
\hline Sumber : Rosanti, 2003 &
\end{tabular}

Sumber : Rosanti, 2003

\section{Evaluasi sediaan salep ekstrak herba Pegagan}

Evaluasi yang dilakukan adalah pemeriksaan kestabilan bentuk sediaan salep, pemeriksaan homogenitas, pemeriksaan warna, dan pemeriksaan bau. Pengamatan dilakukan pada minggu ke-1, 2, 3, 4, 5, 6, 7, 8.

\section{Perlakuan Sediaan Salep Ekstrak Pegagan Pada Mencit}

Sebelum perlukaan, bulu di sekitar punggung dicukur dan kulit diolesi alkohol, lalu mencit diadaptasi selama 2 hari. Mencit dianastesi lokal dengan eter, lalu Perlukaan dilakukan pada punggung mencit dengan sayatan $1.5 \mathrm{~cm}$ menggunakan scalpel steril. Mencit yang digunakan sebanyak 20 ekor yang dibagi menjadi 5 kelompok perlakuan, yaitu kelompok I diolesi dengan formula basis minyak, kelompok II formula basis emulsi, kelompok III formula basis larut air, kelompok IV ekstrak murni serta kelompok 
V diolesi betadin ${ }^{\circledR}$ sebagai kontrol positif. Bahan uji diberikan 2 kali sehari selama 21 hari dan diamati pada hari ke-1,3,7,14, 21. Pengamatan dilakukan secara deskriptif terhadap mencit perlakuan dengan membandingkan proses penyembuhan yang terjadi. Parameter yang diamati antara lain merapatnya kulit, keringnya luka dan keberadaan keropeng luka.

\section{HASIL DAN PEMBAHASAN}

Sediaan salep ekstrak pegagan dapat bercampur (homogen). Hasil pengamatan kestabilan bentuk sediaan salep ekstrak herba pegagan formula I, II, III dari minggu ke I sampai minggu ke- 8 tetap stabil dan tidak mengalami perubahan bau, warna dan tetap homogen pada penyimpanan dan tipe basis salep yang di hasilkan tidak mengalami perubahan.

Pemeriksaan salep ekstrak herba pegagan diamati secara organoleptik. Hasil pengamatan menunjukkan warna salep basis berminyak berwarna hijau, formula II basis salep emulsi berwarna hijau keputihan dan formula III basis salep larut air berwarna hijau kekuningan, dengan demikian basis salep mempengaruhi warna dari sediaan salep ekstrak herba pegagan. Warna sediaan tidak mengalami perubahan selama 8 minggu (stabil) dengan penyimpanan pada suhu kamar. Hasil pengamatan penyembuhan luka pada setiap mencit ditunjukkan pada Tabel 4 dan rata-rata penyembuhan luka pada Tabel 5. Berdasarkan hasil pengamatan bau (aroma), formula I dengan basis minyak cukup kuat, formula II dengan basis emulsi memiliki bau ekstrak pegagan (zat aktif) yang kuat, dan formula III merupakan sediaan salep ekstrak pegagan yang berbasis larut air memiliki aroma yang lemah. Hal ini disebabkan asiatikosida dalam ekstrak pegagan merupakan glikosida triterpenoid yang bersifat non polar sehingga larut dalam basis minyak dan emulsi. Pengamatan bau (aroma) sediaan salep ekstrak pegagan memiliki aroma yang stabil selama 8 minggu dengan penyimpanan pada suhu kamar dan basis salep mempengaruhi bau dari sediaan tersebut. Hal ini dengan penyimpanan pada suhu kamar dan basis salep mempengaruhi bau dari sediaan tersebut. Hal ini dikarenakan sifat kepolaran zat aktif sehingga mempengaruhi kelarutan zat aktif basis yang ditambahkan. Pada perlakuan sediaan salep ekstrak herba pegagagan dilakukan terhadap mencit jantan (Mus musculus albinus). Hasil pengamatan penyembuhan luka antara komponen yang diuji (formula dan hari).

Berdasarkan pengamatan secara makroskopis terlihat bahwa proses penyembuhan luka kelompok III lebih lambat dibandingkan dengan kelompok II, I, IV dan V. Salep formula I (kelompok I) dan betadin ${ }^{\circledR} \quad$ (kelompok V) memperlihatkan perbedaan nyata bila dibandingkan dengan kelompok II dan III. Hal ini terlihat dengan terlepasnya keropeng dan luka menyempit. Pada kelompok I penyembuhan hampir sama dengan kelompok IV sedangkan kelompok (Betadin $®)$ berlangsung lebih cepat. Luka akan mengakibatkan peradangan sehingga mengakibatkan panas di daerah luka tersebut. Pemberian salep ekstrak pegagan akan menimbulkan rasa

dingin pada daerah yang dioleskan (Anonimous, 2007). Diduga salah satu faktor yang menyebabkan percepatan proses persembuhan luka akibat pemberian salep ekstrak herba pegagan adalah daya kompres dingin dari herba pegagan.

Pengobatan dengan meng-gunakan salep akan lebih efektif apabila obat dapat lepas dari basisnya, tipe basis berminyak yang bersifat lipofilik mempunyai afinitas lebih lemah. Afinitas lemah memudahkan zat aktif terlepas dari basisnya, sehingga mudah untuk berdifusi kedalam media (Rosanti, 2003). Berdasarkan pengamatan, proses penyembuhan luka formula I yang berbasis minyak lebih cepat dibandingkan dengan sediaan salep formula II dan III.

Basis berminyak lebih mudah melepaskan ekstrak herba pegagan. Ini disebabkan karena zat aktif dari herba pegagan adalah asiatikosid, yang merupakan senyawa yang bersifat hidrofil sedangkan basis salep bersifat lipofil. Penyembuhan kelompok V lebih cepat (Betadin $®$ ) hal ini disebabkan karena Betadin ${ }^{\circledR}$ mengandung 
providone iodine bekerja sebagai antiseptik bersprektrum luas dan iodine sendiri daerah luka cepat menjadi kering (Saratman, memberi efek panas pada jaringan sehingga dkk, 2004).

Tabel 4. Hasil Pengamatan Penyembuhan Luka Pada Setiap Mencit

\begin{tabular}{|c|c|c|c|c|c|c|}
\hline \multirow[t]{2}{*}{ Formula } & \multirow{2}{*}{ Ulangan } & \multicolumn{5}{|c|}{ Penyembuhan } \\
\hline & & 1 & 3 & 7 & 14 & 21 \\
\hline \multirow{4}{*}{ I } & 1 & 1 & 3 & 5 & 7 & 7 \\
\hline & 2 & 1 & 3 & 5 & 6 & 7 \\
\hline & 3 & 1 & 2 & 4 & 6 & 7 \\
\hline & 4 & 1 & 3 & 5 & 6 & 7 \\
\hline \multirow{4}{*}{ II } & 1 & 1 & 2 & 3 & 6 & 7 \\
\hline & 2 & 1 & 2 & 3 & 6 & 7 \\
\hline & 3 & 1 & 2 & 3 & 6 & 7 \\
\hline & 4 & 1 & 3 & 4 & 6 & 7 \\
\hline \multirow{4}{*}{ III } & 1 & 1 & 2 & 3 & 6 & 7 \\
\hline & 2 & 1 & 2 & 3 & 6 & 7 \\
\hline & 3 & 1 & 2 & 3 & 6 & 7 \\
\hline & 4 & 1 & 2 & 3 & 6 & 7 \\
\hline \multirow{4}{*}{ IV } & 1 & 1 & 3 & 4 & 6 & 7 \\
\hline & 2 & 1 & 3 & 5 & 6 & 7 \\
\hline & 3 & 1 & 3 & 5 & 7 & 7 \\
\hline & 4 & 1 & 3 & 5 & 7 & 7 \\
\hline \multirow{4}{*}{$\mathrm{V}$} & 1 & 1 & 3 & 5 & 7 & 7 \\
\hline & 2 & 1 & 4 & 5 & 7 & 7 \\
\hline & 3 & 1 & 3 & 5 & 6 & 7 \\
\hline & 4 & 1 & 3 & 5 & 7 & 7 \\
\hline
\end{tabular}

Keterangan :

1. Luka berwarna merah, basah, masih terbuka, tepi luka masih terpisah.

2. Luka berwarna merah pucat, agak kering, luka terbuka \& tepi masih terpisah.

3. Luka kering \& pucat, tepi kering luka menyempit, kulit tepi keras.

4. Luka menyempit dan dangkal, tepi luka keras, terbentuk keropang.

5. Tampak sisa-sisa keropang, bekas luka menjadi lunak, luka menyempit.

6. Luka mulai menutup bekas keropeng tidak ada lagi.

7. Luka sudah menutup, bekas luka tidak tampak lagi dan ditumbuhi bulu seperti semula.

Tabel 5. Rata-rata Penyembuhan Luka Antara Komponen yang Diuji (Formula dan Hari) Selama 21 Hari.

\begin{tabular}{|c|c|c|c|c|c|c|}
\hline \multirow{2}{*}{ Formula } & \multicolumn{5}{|c|}{ Rata-rata penyembuhan pada hari ke- } & \multirow{2}{*}{ Rata-rata } \\
\hline & 1 & 3 & 7 & 14 & 21 & \\
\hline I & 1 & 2.75 & 4.75 & 6.25 & 7 & $4.35^{\mathrm{a}}$ \\
\hline II & 1 & 2.25 & 3.25 & 6 & 7 & $3.9^{b}$ \\
\hline III & 1 & 2 & 3 & 6 & 7 & $3.8^{b}$ \\
\hline IV & 1 & 3 & 4.75 & 6.5 & 7 & $4.45^{\mathrm{a}}$ \\
\hline $\mathrm{V}$ & 1 & 3.25 & 5 & 6.75 & 7 & $4.6^{\mathrm{a}}$ \\
\hline
\end{tabular}

Keterangan : Angka yang diikuti huruf yang berbeda pada kolom dan lajur yang sama berbeda nyata 


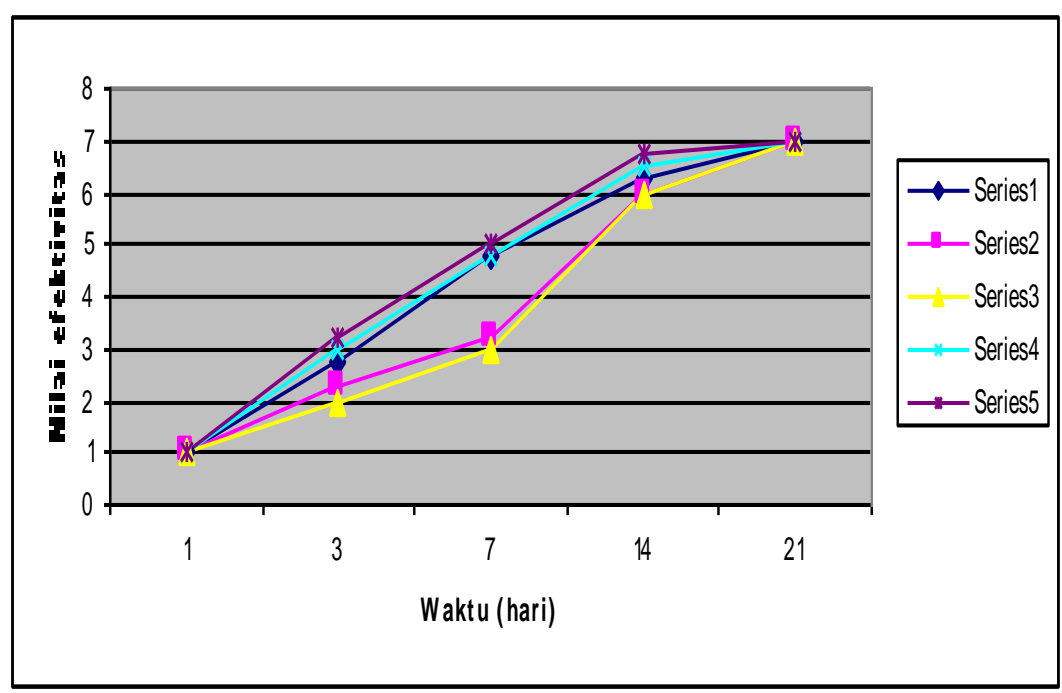

Gambar 1. Grafik Rata-rata Penyembuhan Luka Antara Komponen yang Diuji (Formula dan Hari) Selama 21 Hari.

Berdasarkan grafik, terlihat bahwa tipe basis salep mempunyai perbedaan yang bermakna terhadap aktivitas penyembuhan luka pada mencit. Hal ini dapat dilihat pada tabel ANOVA atau uji $\mathrm{F}$ tabel dan $\mathrm{R}^{2}$ yang cukup signifikan dilihat dari $\mathrm{F}$ hitung 364,34 yang lebih besar dibandingkan dengan $\mathrm{F}$ tabel dan $\mathrm{R}^{2}$ yang cukup besar yaitu $0,978514(97,85 \%)$. Berdasarkan program software SAS (Statistical Analyze System) metode Rancangan Acak Lengkap (RAL) dan uji dilanjutkan dengan uji Duncan, menunjukkan bahwa formula 5, 4, 1 lebih efektif dibandingkan dengan formula 3 dan 2. Hasil uji disajikan pada Tabel 5.

Adanya perbedaan yang bermakna, maka hal ini membuktikan bahwa tipe basis berminyak merupakan tipe basis yang paling baik untuk ekstrak herba pegagan dan adanya perbedaan antara komponen yang diuji (signifikan) antara formula dan hari.

\section{SIMPULAN DAN SARAN}

\section{Simpulan}

1. Salep ekstrak herba pegagan efektif menyembuhkan luka terhadap mencit jantan.

2. Basis salep berminyak lebih efektif menyembuhkan luka terhadap mencit jantan dibandingkan dengan basis emulsi dan basis larut air.

3. Proses penyembuhan luka mencit jantan yang mendapat perlakuan pengobatan: kelompok V (obat luka komersil (betadin $®)$ ), kelompok IV (ekstrak kental pegagan), kelompok I (salep ekstrak pegagan dengan basis berminyak), lebih efektif dibandingkan dengan kelompok II (salep ekstrak pegagan basis emulsi) dan kelompok III ( salep ekstrak pegagan basis larut)

\section{Saran}

Perlu dilakukan penelitian lebih lanjut mengenai :

1. Kesetabilan kesediaan salep ekstrakherba pegagan basis berminyak dengan suhu yang berbeda.

2. Khasiat herba pegagan terhadap penyembuhan luka setelah operasi (keloid) dengan konsentrasi zat aktif yang sama dalam sedian salep ekstrak herba pegagan basis berminyak

3. Memberikan informasi kepada masyarakat luas bahwa ekstrak herba pegagan dapat ditambahkan

ke dalam formula salep dan dapat digunakan sebagai alternatif obat luka.

\section{Ucapan terima kasih}

Terima kasih diucapkan kepada Prof. Dr. Anas Subarnas, Apt. sebagai mitra bestari dalam penulisan penelitian ini.

\section{DAFTAR PUSTAKA}

Anief, M. Formulasi Obat Topikal Dengan Dasar penyakit Kulit. Yogyakarta;Gajah 
Mada Press: 1997. 3-32.

Anonimous.1983.Pemanfaatan

tanaman

Obat Edisi III. Departemen Kesehatan Republik Indonesia.

Ansel, H. C, L. V. Allen and N. G. Popovich. 2002.Pharmaceutical Dosage Form and Drug Delivery System. Lippincott William and Wilkins, Georgia, Jakarta: Hal 250, 375, 377.

Block, L. H. 1990. Medicated Application, in Gennaro, AR.(Ed.), Remington's Pharmaceutical Science, $18^{\text {th }}$ ed. Mack Publishing Company, Easton Pensylvania, 1596-1614.

Davis and Christopher. 1981. Texbook of Surgery, The Biological Basis of Modern Surgical Practice. WB Saunders Company, Philadelphia, 265-283.

Departemen Kesehatan RI. 1979. Farmakope Indonesia Edisi III. Depkes RI, Jakarta.

Endah, L., M. M. Herminawati dan Y. I. Hety. 2003. Pegagan. Penebar Swadaya. Jakarta.
Ernie, H. 2005. Pembuatan Salep Vaselin Hidrofilik Dengan Ekstrak Herba Pegagan (Centella asiatica(L) Urb) untuk Luka. Skripsi, Fakultas Farmasi, Universitas Pancasila.

Lachman, L., H. A. Lieberman and J. L. Konig. 1994. Teori dan praktek farmasi industri.Edisi III, jilid II. Diterjemahkan oleh Suyatmi S. Jakarta: UI Pres : Hal 1091-1145.

Rosanti, A. S.,N. Sugihartini, dan Oetari. 2003. Pengaruh Tipe basis Salep Terhadap Aktivitas minyak Atsiri Daun Sirih (Piper betle Linn.)

Saratman., S. A. Sumiwi dan D. Gozali. 2004. Pengaruh Ekstrak Antanan dalam Bentuk Salep, Krim dan Jelly Terhadap Penyembuhan Luka Bakar. Skripsi Fakultas Matematika dan Ilmu Pengetahuan Alam. Universitas Padjadjaran, Bandung. 